\title{
Growth and mortality of the fish Citharichthys xanthostigma (Pleuronectiformes: Paralichthyidae) off the Western coast of Baja California, México
}

\author{
Marco A. Martínez-Muñoz ${ }^{1} \&$ Armando A. Ortega-Salas ${ }^{2}$ \\ 1. Unidad Profesional Interdisciplinaria de Ingeniería y Ciencias Sociales y Administrativas, I. P. N. Hocaba esq. \\ Hopelchen Manz-353 L-1. Torres de Padierna. C. P. 14200, México, D. F.; marcoam@servidor.unam.mx \\ 2. Unidad Académica Mazatlán, Instituto de Ciencias del Mar y Limnología, UNAM. Calzada Joel M. Camarena s/n, \\ Mazatlán 82040, Sinaloa, México. Apdo. Post. 811. Fax: (669) 9826133 and (669) 9813688; \\ ortsal@ola.icmyl.unam.mx
}

Received 20-II-2009. C Corrected 08-X-2009. Accepted 01-XI-2009.

\begin{abstract}
Longfin sanddab (Citharichthys xanthostigma) represents a very important fishery resource in Southern and Baja California but are not very well known. The purpose of this study is to provide information on the growth and mortality of longfin sanddab population in the Mexican Pacific Ocean at Baja California, México. Data on growth were obtained for longfin sanddab collected with otter trawls during six cruises off the Western coast of Baja California. A total of 1017 longfin sanddab were caught over the sampling period, and from 860 specimens, the male to female ratio was $1: 1.8$. The relationship between total weight (W) and standard length (SL) is described: $\mathrm{W}=0.00000743 \mathrm{SL}^{3.196}$ for females and $\mathrm{W}=0.00000764 \mathrm{SL}^{3.193}$ for males. Age groups were estimated from length frequency data, and von Bertalanffy annual growth parameters for all fish data combined were the following: $\mathrm{L}_{\infty}=289.2 \mathrm{~mm} \mathrm{SL}, \mathrm{k}=0.20, \mathrm{t}_{0}=-0.73$; for males, they were $\mathrm{L}_{\infty}=265.9 \mathrm{~mm} \mathrm{SL}$, $\mathrm{k}=0.21, \mathrm{t}_{0}=-0.68$, and for females, $\mathrm{L}_{\infty}=293.6 \mathrm{~mm} \mathrm{SL}, \mathrm{k}=0.23, \mathrm{t}_{0}=-0.35$. Longfin sanddab caught during this study reached a maximum age of 10 years, and at that age, males attained smaller sizes than females. The age groups had a total mortality $(\mathrm{Z})$ rate of 0.82 year $^{-1}$, a fishing mortality $(\mathrm{F})$ of 0.52 year $^{-1}$, and a natural mortality (M) of 0.3 year $^{-1}$. Although the longfin sanddab is not a target species of commercial fisheries, it suffers high mortality as part of the bycatch in the shrimp fishery. Rev. Biol. Trop. 58 (2): 689-705. Epub 2010 June 02.
\end{abstract}

Key words: flatfish, Pleuronectiformes, C. xanthostigma, growth, mortality, bycatch shrimp, Baja California.

Sanddab flatfish are highly prized by the commercial industry and by recreational anglers for their excellent edibility. Four species of sanddabs are found in Californian and Baja Californian waters: Pacific sanddab (Citharichthys sordidus), longfin sanddab (C. xanthostigma), speckled sanddab (C. stigmaeus), and gulf sanddab ( $C$. fragilis).

Pacific sanddab and longfin sanddab are caught in Southern California and Baja California. Sanddab landings were the highest recorded, approximately 1.44 million pounds were landed in 1990, but landings crashed in
1992 to 0.6 million pounds, and then rebounded to more than 2.0 million pounds in 1997 and 1999. The commercial catch of sanddabs is mainly accomplished through otter trawls and some by hook-and-line (Allen \& Leos 2001).

Off the Western coast of Baja California, flatfishes are an import ant component of the shrimp bycatch, and they constitute an important fisheries resource (van der Heiden 1985, Balart 1996). Longfin sanddab, C. xanthostig$m a$, (Family Paralichthyidae) live on sandy and muddy bottoms in depths from 3 to $200 \mathrm{~m}$, normally on the outer continental shelf (Miller 
\& Lea 1972), from Monterey Bay, California, to Costa Rica on the Pacific coast, are warmtemperate to tropical species (Castro-Aguirre et al. 1992, Abitia-Cardenas et al. 1994, De la Cruz Agüero et al. 1994, Rodriguez-Romero et al. 1994, Moser \& Sumida 1996, RosalesCasián 1996, Allen \& Leos 2001). Most of these papers comprised only descriptions of the species and common data on its early stages, geographic range, depth inhabited and occurrence. Longfin sanddab preys on polychaets, crustaceans and euphausids (Allen 1982). This species is also a winter spawner (Goldberg 1982).

A fishery on flatfish in Baja California is artisanal and multispecific; twenty or more species of bony fish and elasmobranchia are usually caught.

Pérez-Mellado \& Findley (1985) estimated $20 \%$ of longfin sanddab from the shrimp fishery catches in the coast of Sinaloa and Sonora.

This resource is exploited all the year round, mainly from May to September. Registers from the fisheries office do not included incidental caught associated to the shrimp fisheries. Between 70 and $100 \%$ are fishes which included 29 flatfish among them 15 are considered frequent and dominant such as the Paralichthyidae family. There are about 37 species of flatfish in Baja California. Due to its size and accessibility there are few caught as commercial target and they do not have any register of catch like P. californicus, Hippoglossina spp, Xystreurys liolepis, Cyclopsetta spp and Citharichthys spp. During 1990-1994 periods, the catches varied between 358 and 725 tons per year; $98.8 \%$ of the production is processed gutted and iced; the rest is filleted, frozen or seller as individual fish for a national market or exported to San Diego, USA.

It is unknown the fisheries effort through all the year, reason why it is impossible to know the level of exploitation and efficiency of the applying methods during all the year round. Bottom trammel nets are used, trawls, seines and various types of hooks.

There were no closed seasons for fishing of this resource; there are no special restrictions on access to this fishery; join the social sector (fishing cooperatives) and fishery private companies. The gear is prohibited trawling in protected marine waters.

The purpose of this study is to provide information on the growth and mortality of the longfin sanddab population in the Mexican Pacific Ocean at Baja California, México, for its use in managing this species as a fishery resource.

\section{MATERIALS AND METHODS}

Fish were collected from April 1988 to July 1989 from 90 otter trawls conducted during the course of six cruises aboard the R/V EL Puma and R/V Marsep XVI. All fish were collected using an otter trawl that measured $20 \mathrm{~m}$ wide and $9 \mathrm{~m}$ high at the mouth, $24 \mathrm{~m}$ in length, with a stretched mesh size of $3 \mathrm{~cm}$ and cod mesh of $1.5 \mathrm{~cm}$. Trawling time and speed were recorded to estimate the area swept by the net. Trawling speed ranged between 1.1 and $1.5 \mathrm{~m} \mathrm{~s}^{-1}$. Trawls were towed for $30 \mathrm{~min}$ along isobaths (10 to $250 \mathrm{~m}$ ).

Thirty four sampling stations were located off the Western coast of Baja California, from "Boca del Carrizal" $\left(23^{\circ} 00^{\prime} \mathrm{N}\right)$ to Sebastian Vizcaino Bay $\left(28^{\circ} 51^{\prime} \mathrm{N}\right)$ at depths of 10 to $250 \mathrm{~m}$ (Fig. 1). The sample sizes were not proportional to the estimated area of the strata. Bottom temperatures varied between 11 and $19^{\circ} \mathrm{C}$.

Specimens of longfin sanddab were measured to the nearest millimeter standard length (SL), wet weighed (W) to the nearest gram, and sexed visually immediately after being caught.

The length frequencies of male and female fish were plotted to examine the relationship between length and sex for all fish combined $(n=860)$. Length measurements of the longfin sanddab were classified into size groups with a class interval of $10 \mathrm{~mm}$ and length-frequency distribution of each prepared sample. The samples were combined according to months and the monthly distributions were constructed and used in growth estimation. Variability in standard length and weight frequency distributions 


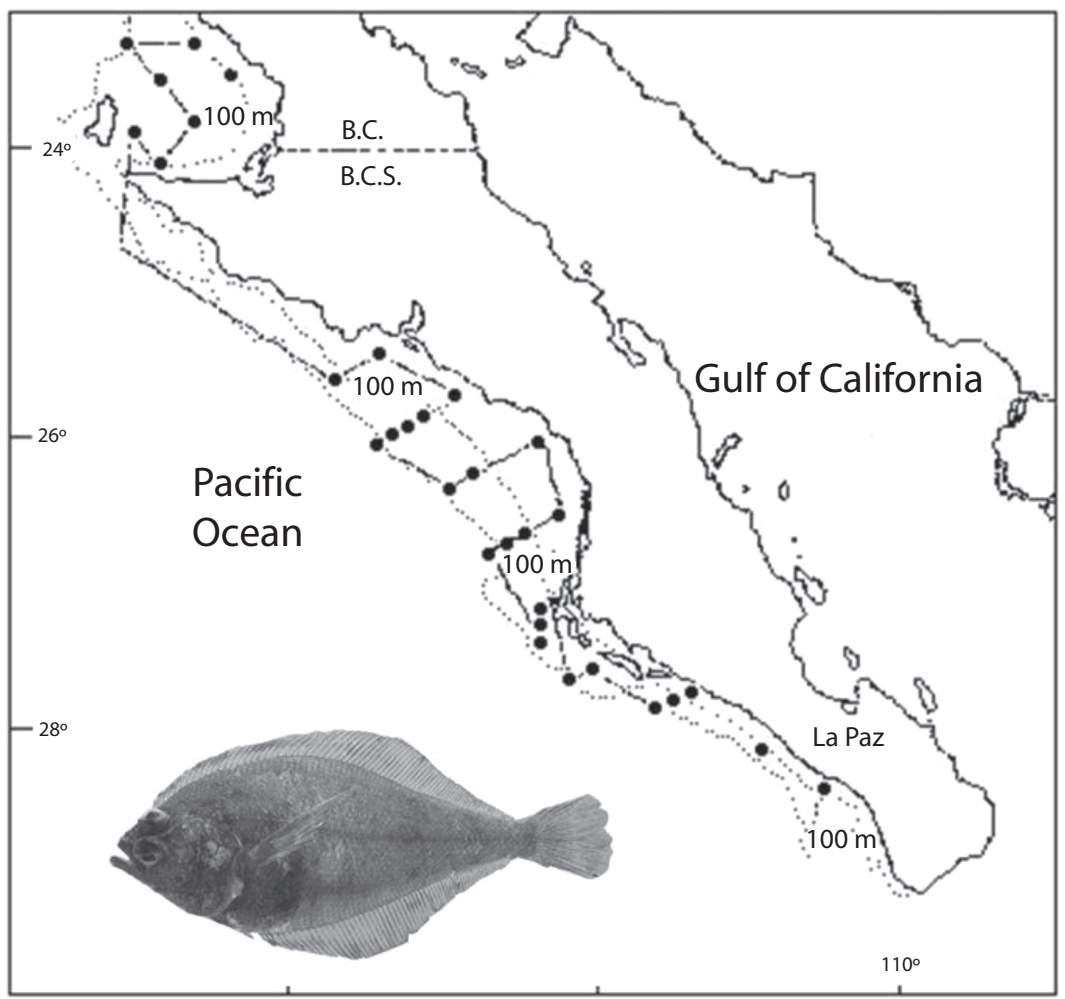

Fig. 1. Sampled stations of C. xanthostigma in Baja California, México.

of males and females were compared with Kolmogorov-Smirnov two-sample tests (Sokal \& Rohlf 1995).

These data were used to calculate the length-weight relationship varying the logarithmic of the equation $\mathrm{W}=\mathrm{a} \mathrm{SL}^{\mathrm{b}}$ for each sex, where $\mathrm{W}$ is weight in grams, $\mathrm{SL}$ is the standard length (mm), a-values is the y-intercept and b is the slope (Wooton 1990, Anderson \& Neumann 1996). Differences in b-values between sexes were calculated through covariance analysis (ANCOVA) (Zar 1999) and the hypothesis of isometric growth $(b=3)$ through the t-test. Male and female regression coefficients were compared with ANCOVA.

The von Bertalanffy growth equation (BVGE) for length and weight was used to obtain growth curves of the longfin sanddab (Beverton \& Holt 1957, Ricker 1975, Gulland
1983): $\mathrm{SL}_{\mathrm{t}}=\mathrm{SL}_{\infty}\left(1-\mathrm{e}^{-\mathrm{k}(\mathrm{t}-\mathrm{t} 0)}\right)$ and $\mathrm{Wt}=\mathrm{W}_{\infty}(1-\mathrm{e}$ $-\mathrm{k}(\mathrm{t}-\mathrm{t} 0))^{\mathrm{b}}$.

Where: $\mathrm{SL}_{\mathrm{t}}=$ is the length at time $\mathrm{t}(\mathrm{mm})$; $\mathrm{SL}_{\infty}=$ the asymptotic standard length (mm); $\mathrm{k}=$ the rate at which length tends towards asymptote; $\mathrm{W}_{\mathrm{t}}=$ the body weight of fish at time $\mathrm{t}(\mathrm{g}) ; \mathrm{W}_{\infty}=$ the asymptotic body weight of fish $(\mathrm{g}) ; \mathrm{t}_{0}=$ the theoretical age at which growth appears to start.

The seasonal von Bertalanffy growth function (VBGF) was used to estimate growth parameters: $\mathrm{SL}_{\mathrm{t}}=\mathrm{SL}_{\infty}\left(1-\mathrm{e}^{(-\mathrm{k}(\mathrm{t}-\mathrm{t} 0)}+\mathrm{St}_{\mathrm{s}}-\mathrm{St}_{0}\right)$, where, $\mathrm{St}_{\mathrm{s}}=\left(\mathrm{Ck} / 2 \sigma^{*} \sin \left(2 \varpi\left(\mathrm{t}-\mathrm{t}_{\mathrm{s}}\right)\right) ; \mathrm{St}_{0}=(\mathrm{Ck}\right.$ $/ 2 \pi * \sin \left(2 \varpi\left(\mathrm{t}_{0}-\mathrm{t}_{\mathrm{s}}\right)\right)$.

For the seasonal VBGF, $\mathrm{SL}_{t}$ is the standard length at time $\mathrm{t}, \mathrm{SL}_{\infty}$ is the asymptotic standard length $(\mathrm{mm}), \mathrm{k}$ is the growth coefficient $\left(\right.$ year $\left.^{-1}\right) t_{0}$ the age of fish at zero length (year), $\mathrm{t}_{\mathrm{s}}$ the time between $\mathrm{t}=0$ and start of 
a sinusoid growth oscillation [replaced with winter point (WP) that is equal to $\left.t_{s}+0.5\right]$, and $\mathrm{C}$ is the amplitude of growth oscillations. The WP expresses the time of the year when growth is the slowest, and $\mathrm{C}=0$ indicates non-seasonal growth (Sparre \& Venema 1992).

Data analysis was done using routines in FISAT software (Gayanilo et al. 1994). Estimation of growth parameters was conducted using the ELEFAN I routine incorporated in the FISAT. Algorithms of the routine require that the $\mathrm{L}_{\infty}$ parameter is known, at least to within a biologically acceptable range. Initial values of $\mathrm{L}_{\infty}$ were obtained (with $\mathrm{SE}_{\mathrm{s}}$ ) based on the assumption that the maximum length in the sample and asymptotic length are closely related, computed from the equation derived by Froese \& Binohlan (2000). The ELEFAN estimates only two of the three growth parameters $\left(\mathrm{L}_{\infty}\right.$ and $\left.\mathrm{k}\right)$, thus, we computed the third parameter $\left(\mathrm{t}_{0}\right)$ by the empirical equation of Pauly (1983) for growth fitting: $\log \left(-t_{0}\right)=(-0.3922)-$ $0.2752 \log \mathrm{L}_{\infty}-1.038 \log \mathrm{k}$.

Final growth estimates (with seasonality) were obtained using the ELEFAN I routine (Pauly \& David 1981). Parameter estimates of the von Bertalanffy equation for males and females were compared with a likelihood-ratio test (Chen et al. 1992a) to determine the difference in growth between sexes. To do this, for each data set (males and females), a curve was fitted to the mean length for each age. Finally, growth parameters were fitted using maximum likelihood to reduce the residual sum squares with the solver routine.

Natural mortality (M) was estimated using the empirical formula (Pauly 1980):

$$
\begin{aligned}
\log (\mathrm{M})= & (-0.0066)-0.279 \log \left(\mathrm{L}_{\infty}\right)+0.6543 \\
& \log (\mathrm{k})+0.4634 \log (\mathrm{T})
\end{aligned}
$$

Where, $\mathrm{L}_{\infty}$ and $\mathrm{k}$ are the VBGF parameters, and $\mathrm{T}^{\circ} \mathrm{C}$ is the mean environmental temperature $\left(21^{\circ} \mathrm{C}\right.$ during this study).

The total mortality rate, $Z$, was estimated for the population, using age-based catch curves (Ricker 1975, Sparre \& Venema 1992): a) assuming no size or age-selective catchability, b) $\mathrm{Z}$ is constant in all the considered groups,

c) all the considered age groups in the plot are recruited with the same abundance, d) all the considered age groups in the plot are equally vulnerable to the gear used for the sampling, e) the sample is sufficiently large and covers the age groups sufficiently to represent the average population structure in the considered period of time, f) under assumption of constant rate of mortality, numbers surviving $\left(\mathrm{N}_{\mathrm{t}}\right)$ will tend to decline exponentially with time or age $(t)$, as shown by the exponential decay expression of $N_{t} / N_{0}=\exp \left(-Z_{t}\right)$, where $\mathrm{N}_{0}$ is the initial number of individuals at time $\mathrm{t}=0$ and $\mathrm{N}_{\mathrm{t}}$ the number surviving at time $\mathrm{t}$ with $\mathrm{z}$ as the mortality coefficient (Ricker 1975). Total mortality, Z, was also estimated by the mean length method (Beverton \& Holt 1957). Plotting the natural logarithms of the number of fish over age (years) provides a catch curve with a slope that is equal to the instantaneous annual mortality rate, $\mathrm{Z}$, for those age classes that are fully recruited (King 1995). The difference between the instantaneous total mortality coefficient $(Z)$, which includes migration and natural mortality coefficient $(\mathrm{M})$, gave an estimate of fishing mortality $(\mathrm{F}): \mathrm{F}=\mathrm{Z}-\mathrm{M}$, where $\mathrm{F}$ is the fishing mortality $(\mathrm{F}=\mathrm{Z}-\mathrm{M})$ (Sparre \& Venema 1992).

\section{RESULTS}

Fish from all trawls were combined so that 1017 longfin sanddab, ranging in size from 60 to $290 \mathrm{~mm} \mathrm{SL}$ and weights from 3.5 to $437.5 \mathrm{~g}$ were registered. We sampled 922 longfin sanddab, 393 (42.6\%) were females, 467 (50.7\%) were males, and the sex of $62(6.7 \%)$ were undetermined; hence, the female to male ratio was 1:1.2 (Fig. 2). A chi square test showed no significant difference between the proportion of females and males $\left(x^{2}=6.3674\right.$, d.f. $=1$, $\mathrm{p}<0.01)$.

Length-frequency analysis by sex of longfin sanddab shows a very large proportion of males in the smaller size classes, whereas females seem to dominate the larger size classes. However, both males and females 


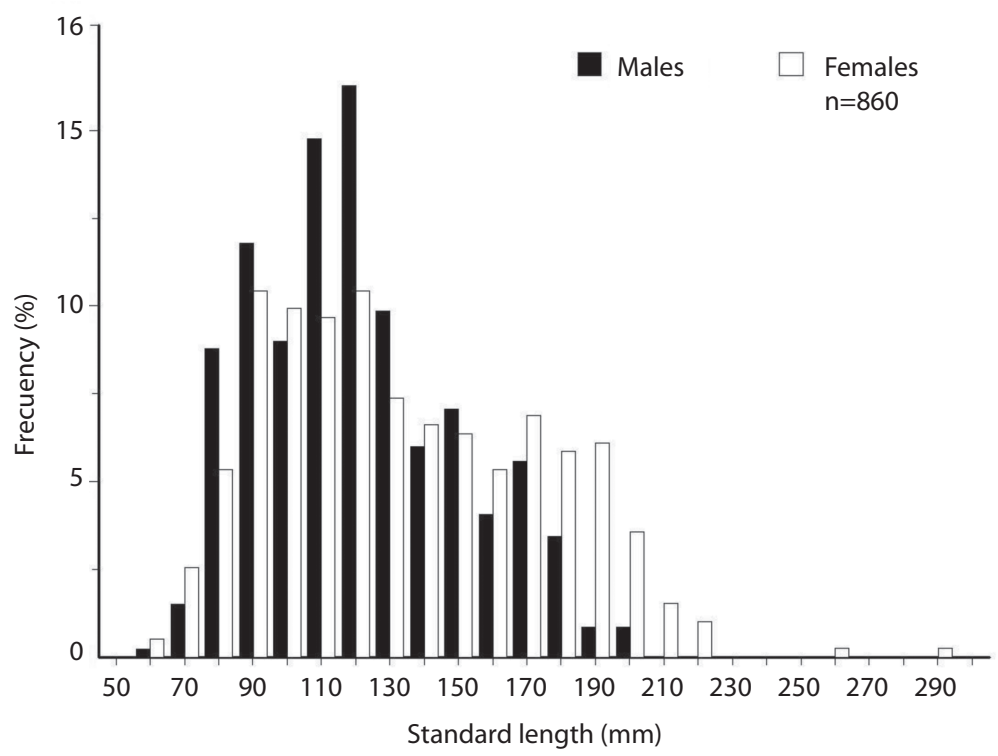

Fig. 2. Length frequency distributions of C. xanthostigma.

were consistently represented throughout the size classes. Distribution of length and weight frequency differed according to sex. Male and female specimens ranged from 56 to $195 \mathrm{~mm}$ SL and from 60 to $290 \mathrm{~mm} \mathrm{SL}$, respectively (Table 1). Both sexes exhibited multimodal distributions; males show the greatest numbers at $117 \mathrm{~mm} \mathrm{SL}$, compared to $129 \mathrm{~mm}$ SL for females (Fig. 2). A higher proportion of males was smaller than females regarding length distributions, using the two-sample Kolmogorov-Smirnov test $(\mathrm{D}=0.42, \mathrm{p}<0.05)$ yielded a significant difference. The t-test and mean differences revealed significant differences between sexes according to the mean standard length $(\mathrm{D}=0.18, \mathrm{p}<0.05)$; confidence interval was $95 \%=8.2-17.4$; d.f. $=858 ; \mathrm{t}=5.43 ; \mathrm{P}=7.14$ $\mathrm{x} 10^{-8}$. Male and female weight ranged from 2.5 to $140.7 \mathrm{~g}$ and 3.5 to $437.5 \mathrm{~g}$, respectively (Table 1). A Kolmogorov-Smirnov test indicated a significant difference between sexes according to the weight $(\mathrm{D}=0.16, \mathrm{p}<0.05)$. Both sexes displayed multimodal distributions in weight, even with mean weight, significant differences between sexes were observed
$(\mathrm{D}=19.1)$; confidence interval was $95 \%=13.3$ 24.9 , d.f. $=858, \mathrm{t}=6.4, \mathrm{p}<2.53 \times 10^{-10}$ (Fig. 3).

Sex composition by size class for all fish in the sample showed similar patterns to those for length. Females are well represented within the older age groups; the oldest fish class $(260 \mathrm{~mm}$ $\mathrm{SL})$ corresponded to females. Males were identified as early as $60 \mathrm{~mm}$ at age -0 (Young-of-the Year, YOY) and were represented in all other age classes except in the I- and II-year classes. An early bias toward females is evident up to $120 \mathrm{~mm}$. Sex ratios appear to be about $1: 1$, throughout the older (6-10 years) size class (age class). Size classes 210, 220, 255 and $290 \mathrm{~mm}$ were represented by only one or four specimens. Immature fish were restricted to the first three age's classes (0-2).

Sex ratios of males and females, grouped into $10 \mathrm{~mm}$ length classes showed a significant departure from the expected 1:1 ( $\chi^{2}$ test, $\mathrm{p}<0.05$ ), except for the size classes from 140 to $170 \mathrm{~mm}$ SL. Males were predominant in the smaller size classes and females in the larger length class samples, all females were larger than 200mm (Table 2 and Fig. 4). Spawning 
TABLE 1

Total weight and standard length data male, female, combined and undetermined of $\mathrm{C}$. xanthostigma in the western coast of Baja California

\begin{tabular}{|c|c|c|c|c|}
\hline Statistics & Males & Females & Combined & Undetermined \\
\hline $\mathrm{N}$ & 467 & 393 & 1017 & 62 \\
\hline SL Minimum & 56 & 60 & 51 & 51 \\
\hline SL Maximum & 195 & 290 & 290 & 105 \\
\hline SL Mean & 117.05 & 129.85 & 120.78 & 71.28 \\
\hline SL SD & 29.05 & 47.0 & 35.89 & 10.06 \\
\hline TW Minimum & 2.5 & 3.5 & 1.8 & 1.8 \\
\hline TW Maximum & 140.7 & 437.5 & 437.5 & 19.8 \\
\hline TW Mean & 38.12 & 129.85 & 45.65 & 6.75 \\
\hline TW SD & 38.87 & 39.59 & 43.98 & 3.11 \\
\hline Parameters & Growth & & & \\
\hline $\mathrm{L}_{\infty}$ & 265.96 & 293.60 & 289.26 & \\
\hline $\mathrm{W}_{\infty}$ & 411.05 & 589.59 & 571.92 & \\
\hline $\mathrm{K}$ & 0.212 & 0.235 & 0.204 & \\
\hline $\mathrm{t}_{0}$ & -0.681 & -0.356 & -0.730 & \\
\hline$r^{2}$ & 0.99 & 0.99 & 0.98 & \\
\hline Parameters & $\mathrm{L}-\mathrm{W}$ relation & & & \\
\hline $\mathrm{a}\left(10^{-6}\right)$ & 7.438 & 7.649 & 6.064 & \\
\hline $\mathrm{b}$ & 3.1939 & 3.1967 & 3.2408 & \\
\hline$r^{2}$ & 0.99 & 0.99 & 0.98 & \\
\hline Parameters & Mortality & & & \\
\hline $\mathrm{Z}\left(\mathrm{yr}^{-1}\right)$ & 0.77 & 0.78 & 0.82 & \\
\hline I. C. & $0.55-1.0$ & $0.56-1.0$ & $0.66-0.97$ & \\
\hline$r^{2}$ & 0.90 & 0.91 & 0.90 & \\
\hline $\mathrm{M}\left(\mathrm{yr}^{-1}\right)$ & 0.31 & 0.32 & 0.30 & \\
\hline $\mathrm{F}\left(\mathrm{yr}^{-1}\right)$ & 0.46 & 0.46 & 0.52 & \\
\hline
\end{tabular}

von Bertalanffy, relation length-weight and mortalities parameters estimates for male, female and combined. Estimates of mortalities and related derived in this study instantaneous total $(\mathrm{Z})$, fishing $(\mathrm{F})$, natural $(\mathrm{M})$ mortalities (year ${ }^{-1}$ ).

individuals were collected from October to July and were dominant during February to July.

The length-weight relationship of combined longfin sanddab gave the following: $\mathrm{W}=0.00000606 \mathrm{SL}^{3.24}\left(\mathrm{r}^{2}=0.98 ; \mathrm{n}=1017\right) ; \mathrm{a}$ positive allometry was established. The hypothesis of isometric growth for this species was discarded, as the obtained allometric index value $(b)$ was significantly different from 3 (Student's t-test, $\mathrm{p}<0.05$ ).

Length and weight were closely correlated with the determination coefficients ranging from
0.99 in both sexes (Fig. 5), which indicated a strong relationship between these two variables $(p<0.001)$. The hypothesis of isometric growth for this species was discarded, as the obtained positive allometric growth index value (b) was significantly different from 3 (t-test, $\mathrm{p}<0.05$ ). No statistically significant differences were found between sexes in the standard lengthtotal weight relationships (ANCOVA, $\mathrm{F}=14.03$, d.f. $859, \mathrm{p}<0.002)$. Therefore, separate models were fitted for each sex: Females: 
TABLE 2

Number and percentage of females, males and undetermined of $\mathrm{C}$. xanthostigma in the western coast of Baja California

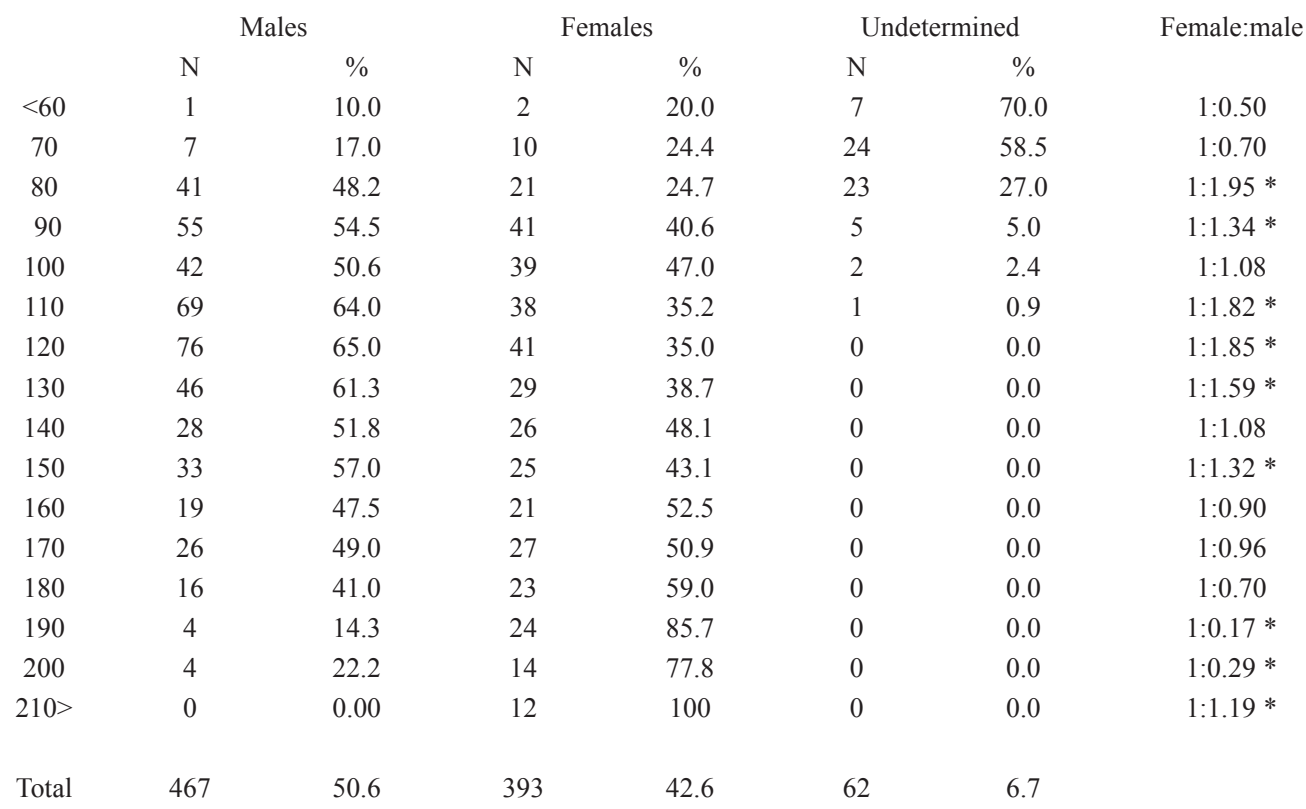

$* \chi^{2}$ test. Statistical difference at $\mathrm{p}<0.05$ from the theorical $1: 1$ sex ratio.

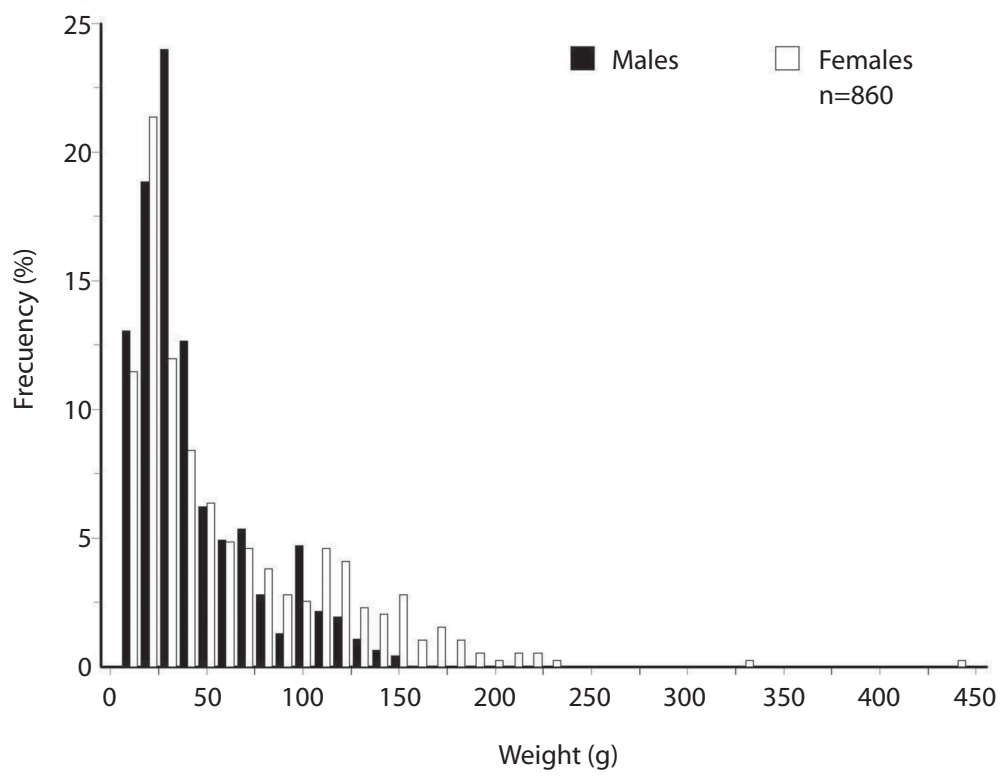

Fig. 3. Weight frequency distributions of C. xanthostigma. 


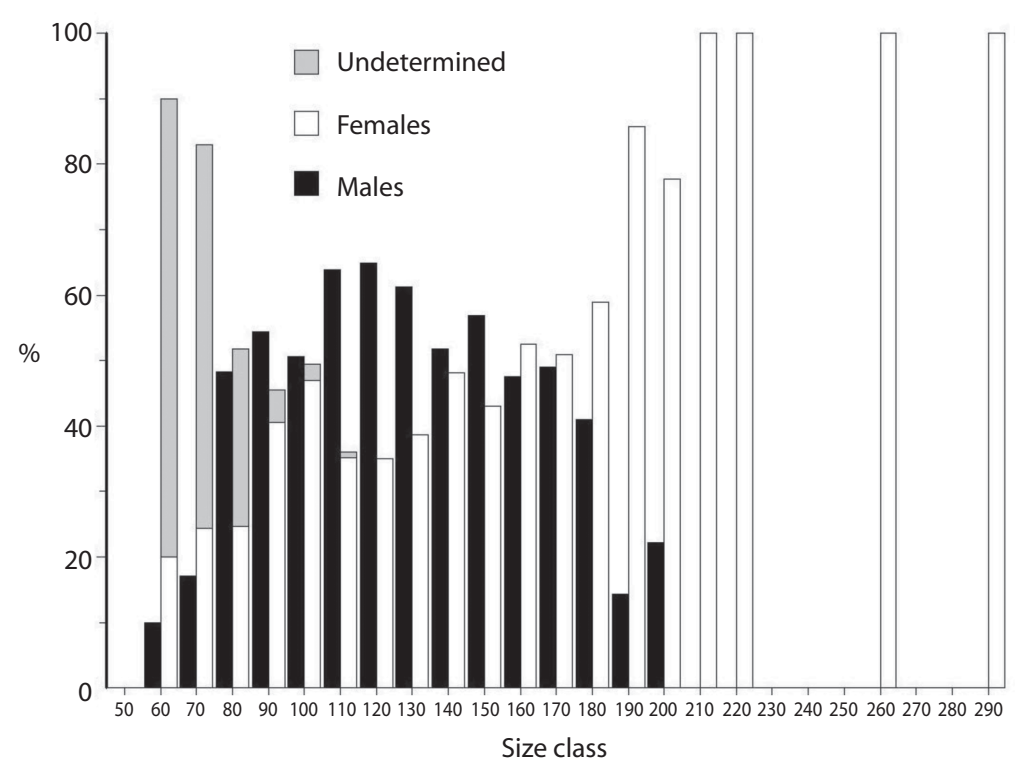

Fig. 4. Percentage of 922 individuals undetermined, female, and male of C. xanthostigma classified by size classes in Baja California, México.

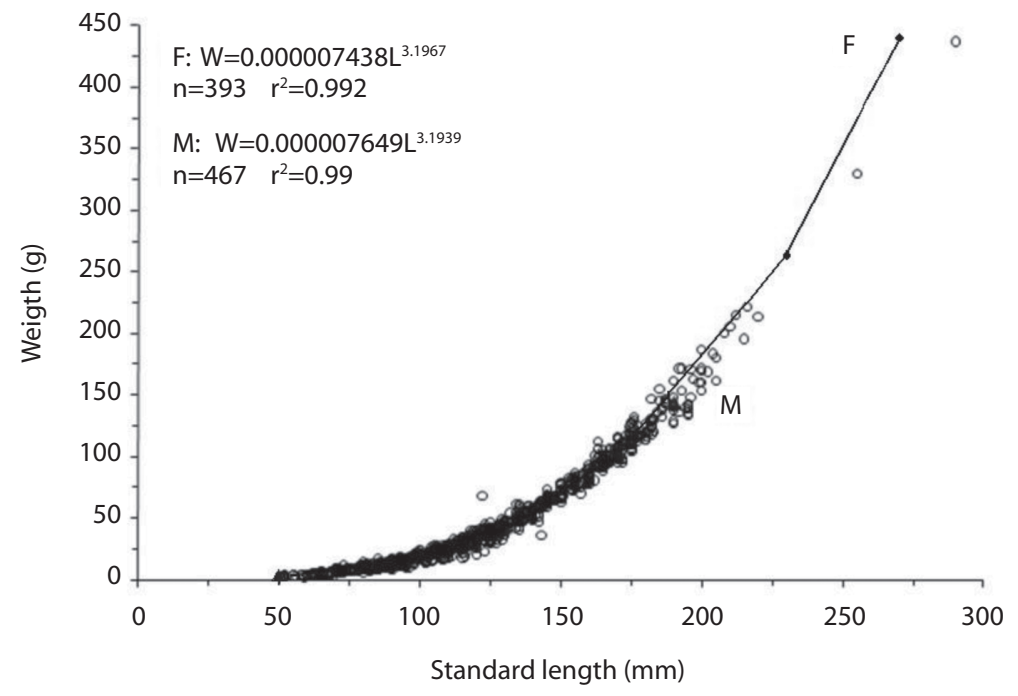

Fig. 5. Length-weight relationships for male and female of C. xanthostigma in Baja California, México ( $\mathrm{n}=860$ ). 
$\mathrm{W}=7.438 \mathrm{X} \quad 10^{-6} \mathrm{~L}^{3.1967} \quad\left(\mathrm{~F}_{1,392}=22106.91\right.$, $\left.\mathrm{p}<0.001, \quad \mathrm{r}^{2}=0.99\right) ; \quad$ Males: $\mathrm{W}=7.469 \quad \mathrm{X}$ $10^{-6} \mathrm{~L}^{3.1939}\left(\mathrm{~F}_{1,465}=13429.76, \mathrm{p}<0.001, \mathrm{r}^{2}=0.98\right)$. The slope shows that females are slightly heavier than males for the same length, females are also bigger. Furthermore, the b-value for males and females was not significantly different (t-test) from the theoretical value of 3.

Initial asymptotic length, computed according to Froese \& Binolhan (2000), was $290 \mathrm{~mm}$, with SE ranging between 257 and $361 \mathrm{~mm}$. These $\mathrm{L}_{\infty}$ ranges, together with the wide range of the $\mathrm{k}$ parameter were analyzed to determine the optimum pairs of growth constants with the best fit. The ELEFAN analysis gave the following seasonalized VBGF growth parameters; relationship between age and length for all aged specimens was adequately described by parameters: $\mathrm{L}_{\infty}=289.26 \mathrm{~mm} \mathrm{SL}, \mathrm{k}=0.20$ year $^{-1}$, and $t_{0}=-0.73$. Computed length-at-age values were as follows: $88.65 \mathrm{~mm}$ (age I), $126.19 \mathrm{~mm}$ (age II), $156.61 \mathrm{~mm}$ (age III), $181.24 \mathrm{~mm}$ (age IV), $201.20 \mathrm{~mm}$ (age V), $217.37 \mathrm{~mm}$ (age VI), $230.47 \mathrm{~mm}$ (age VII), $241.08 \mathrm{~mm}$ (age VIII), $249.67 \mathrm{~mm}$ (age IX), and 256.64mm (age X).
The von Bertalanffy growth equations for males, females, and both sexes were as follows: both sexes: $\mathrm{SL}=289.26\left(1-\mathrm{e}^{-0205}(\mathrm{t}+0.73)\right)$, $\left(\mathrm{F}=137.72, \mathrm{r}^{2}=0.90\right)$; females: $\mathrm{SL}=293.60(1-\mathrm{e}$ $-0235(\mathrm{t}+0.35),\left(\mathrm{F}=4586.28, \mathrm{r}^{2}=0.99\right)$ and males: $\mathrm{SL}=265.96\left(1-\mathrm{e}^{-0212(\mathrm{t}+0.68)}\right), \quad(\mathrm{F}=6081.51$, $\mathrm{r}^{2}=0.99$ ).

After age-group $3(188.9 \mathrm{~mm})$, females were consistently longer and heavier than males due to differences in reproductive condition or general robustness of fish, although the rate of growth $(\mathrm{k})$ for the two sexes was similar. Females attained an older age and longer length than males. Means and standard error of observed length-at-age, and the theoretical von Bertalanffy growth function (VBGF) were plotted for females and males (Fig. 6). It will be seen that the females are on the average slightly larger than the males. As is typical for fish growth curves, the increase in length is more rapid during the first year and shows a fairly constant decline with each successive year. This is true for both (males and females). However, a likelihood ratio test indicated that growth models for males and females

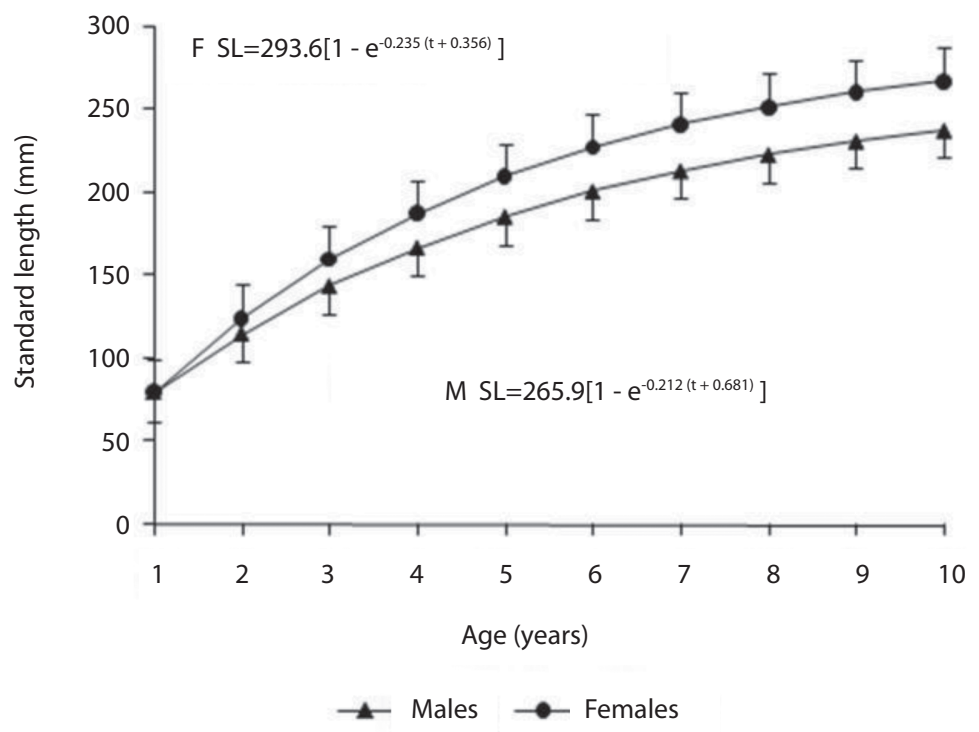

Fig. 6. Growth curve in standard length for female and male of C. xanthostigma, with standard dispersion error at $95 \%$ confidence. 
were significantly different from one another $(F=1.06$, d.f. $=7, p<0.001)$. As expected, the calculated growth curves are relatively smoother. Males and females grow approximately at the same rate for the first four years, at the end of this period fish attain a $208 \mathrm{~mm}$ length. After this, males grow relatively slower than females. At the end of the seventh year, males reach a length of $239 \mathrm{~mm}$, whereas females reach $263 \mathrm{~mm}$. When lengths of male and female fish are compared with the corresponding observed lengths, the two are quite close.

Theoretical weight growth of male and female longfin sanddab is shown in Fig. 7. Females: $\mathrm{Wt}=589.6\left(1-\mathrm{e}^{-0.23(\mathrm{t}-0.35)}\right)^{3.2}$ and males: $\mathrm{Wt}=411.0\left(1-\mathrm{e}^{-0.21(\mathrm{t}-0.68)}\right)^{3.2}$. Results of likelihood-ratio tests showed significant differences in the overall von Bertalanffy weight growth models for males and females $(\mathrm{F}=0.245$, d.f. $=7, \mathrm{p}<0.001$ ).

The instantaneous natural mortality rate (M) obtained using the equation of Pauly (1980) was 0.30 year $^{-1}$; the reliability of the estimated $\mathrm{M}$ was ascertained using the $\mathrm{M} / \mathrm{k}$ ratio for most of the fish (Beverton \& Holt 1957).
The total mortality rate $(Z)$ was estimated using the length-converted catch method, without these, not fully recruited specimens $(0-2+$ years). In addition, the growth in length of the oldest fish, approaching the asymptotic length $\left(\mathrm{L}_{\infty}\right)$, became uncertain with time, hence they were also excluded. Growth rates of the different age-groups (2 years and older) declined with age. The total mean annual mortality was calculated as $\mathrm{Z}=0.82\left(\mathrm{r}^{2}=-0.90\right.$, C.I. of $\mathrm{Z}$ : 0.66 - 0.97 per year $\left.^{-1}, p<0.05\right)$ from the catch curve (Fig. 8) and, apparently, was constant for the age-groups considered. Age-groups 0 and 1 were excluded because of poor efficiency of the sampling net for the smaller fish. Instantaneous mortalities, Z, were estimated at 0.77 for males and 0.78 for females (Table 1). The estimated fishing mortality rate was $\mathrm{F}=0.52$ year $^{-1}$.

\section{DISCUSSION}

The large-sized flatfish species in the coastal waters of Baja California and Gulf of California are Paralichthys californicus,

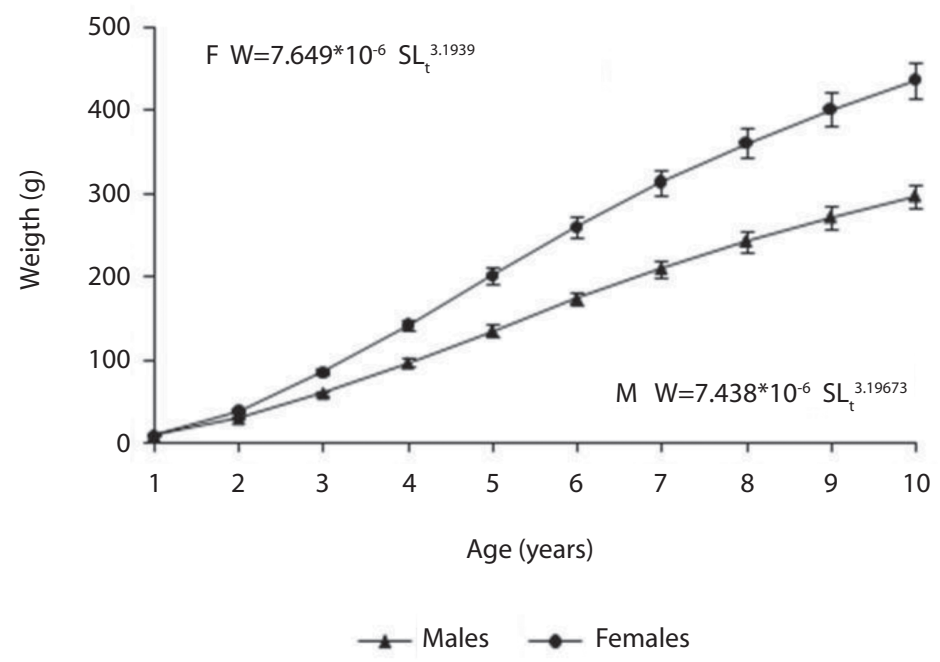

Fig. 7. Curve of growth in weight for female and male of C. xanthostigma, with standard dispersion error at $95 \%$ confidence. 


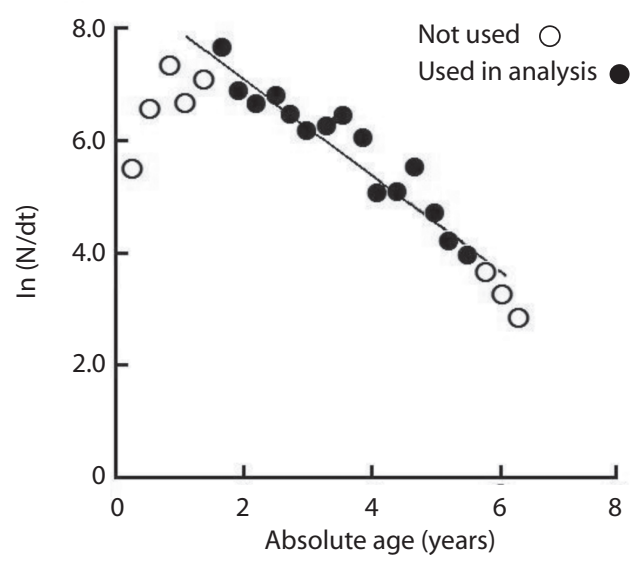

Fig. 8. Catch curve and value of $\mathrm{Z}=0.83$ for $C$. xanthostigma in Baja California, México.

Xystreurys liolepis, and Cyclopsetta querna, others, like Hippoglossina stomata, H. tetrophthalmus, and C. xanthostigma, are between 250 and $350 \mathrm{~mm}$, whereas others, like $C$. platophrys, Syacium ovale, and S. latifrons, are only between $150 \mathrm{~mm}$ and $250 \mathrm{~mm}$. In recent years, the average size of fish in the stock has become smaller, probably as a result of bycatch fishing (Ramirez-Cruz \& MartínezMuñoz 1992). Few previous studies on the biology of the longfin sanddab exist; hence, the growth and mortality parameters estimated here can only be compared to those obtained from studies made in other flatfish species of the Paralichthyidae family (Table 3).

C. xanthostigma population in the western coast off Baja California reaches the same age as other sanddab species found in Californian waters, but it reaches a smaller size-at-age. Discrepancies exist between the maximum reported length and the estimated maximum length for longfin sanddab. The maximum reported length is $250 \mathrm{~mm}$ (Eschmeyer et al. 1983) and the standard length registered for the present study was of $290 \mathrm{~mm}$. The asymptotic length $\left(\mathrm{L}_{\infty}\right)$ is found to be slightly smaller than those estimated for C. sordidus by Arora (1951). The growth rate $(\mathrm{k})$ of the species in the coast of Baja California is relatively slow, as mentioned by other authors (Table 3 ). The estimated value of $\mathrm{L}_{\infty}(289.3 \mathrm{~mm} \mathrm{SL})$ is slightly lower than the maximal total length of 290 observed in the VBGE, which has a good predictive value only for the age-classes between 1 and 9 years, and does not accurately describe the growth during the early and later stage of the fish life.

Arora (1951) found similar results in ageing C. sordidus from the Southern California; their growth rate tends to be very fast in the juvenile stages and slows down considerably in the adult stages. This suggested that the differences in growth between juvenile and adult stages of the sanddabs $C$. sordidus and C. xanthostigma from the coastal waters of California and Baja California may be attributed to the differences in the environmental conditions between the different stages of their development.

Growth in sanddabs has been shown to be regulated by numerous factors; prey availability, population density, environmental temperature, salinity, and suitable habitat (Chamberlain 1979).

The 0 group (i.e., fish in their first year of life) is not well enough represented in the samples collected during July and October to produce distinct modes. This is undoubtedly due to the fact that spawning takes place chiefly during these months and the collections did not include the smallest fish in proportion to their abundance in the population (RamírezCruz \& Martínez-Muñoz 1992). It may well be that the size of the mesh of the net permitted them to escape. The samples collected in October and March, however, show clearly the appearance of group 0 , although the modes are not very sharply defined. The fish during these months have attained a modal length of about $83.4 \mathrm{~mm}$ and, evidently, are retained by the net of $3 \mathrm{~cm}$ mesh.

Throughout development, weight increased at a rate slightly higher than the cube of the length compared with $C$. sordidus, the increases in weight are very different, because it is duplicated to the same sizes.

The difference in growth sizes is almost of $50 \mathrm{~mm}$, and it increases with greater sizes, this 


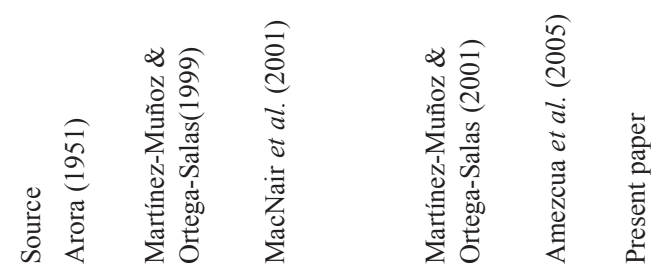

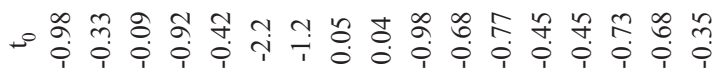

^竎产

:

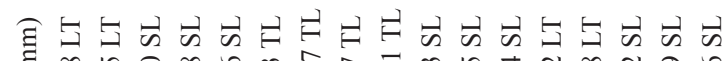

进 $\infty$ n 0 . 0 .

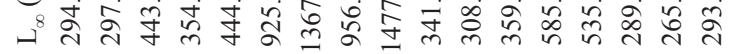

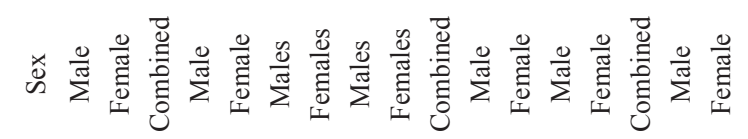

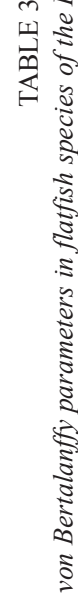


relation follows a pattern similar to C. sordi$d u s$. The length average for the relative age is very similar to those obtained for the Pacific sanddab by Arora (1951) with the methods of scales, otoliths, and length-frequency distribution analysis.

Growth of the longfin sanddab shows similar features to another flatfish: females are longer than males; adult females being heavier than males for the same length. Thus, whereas males dominate the younger age-groups, females are more abundant in the older groups (Martínez-Muñoz \& Ortega-Salas 1999, 2001). The so-called 'short male fish' or 'dwarf-typed male fish' has become one of the important growth characteristics among flatfish, like the most flatfishes (Chen et al. 1992b) females were considerably larger in length and weight than males. The data in our study confirmed that females grow faster than males, as found in previous studies (Martínez-Muñoz \& OrtegaSalas 1999, 2001).

Seasonal variation in growth is similar to that in Pacific sanddabs; the most rapid growth is during summer and early fall. At the end of the fifth year, longfin sanddabs attain $75-85 \%$ of the average standard length and $70 \%$ of the average weight attained at the end of the fifth year, this proportional relation is quite different in C. sordidus and C. stigameus (Arora 1951, Ford 1965, Chamberlain 1979). Many factors can affect growth rates, including differences in the seasonality of spawning, environmental factors, amount, size of food and genetics (Weatherly \& Gill 1987, Moyle \& Cech 1988).

Other factors that may have affected the growth parameters include the following: method of collection and time periods of sampling.

Flatfish possess a life-span normally up to 5-6 year classes for each species (Chen et al. 1992b), while the oldest fish are even more than 10 years old (Martínez-Muñoz \& OrtegaSalas 1999, 2001). In the Pacific sanddab, the growth rate is faster and the life span (8-10 years) is longer than in the speckled sanddab (3-4 years) (Arora 1951, Ford 1965). However, the age compositions of males and females of the same stock are clearly different. The females live longer and show more age groups in the catches.

By comparison, longevity estimates for a variety of other flatfishes, occurring in temperate latitudes and from families other than the Paralichthydae, range from 3 to 23 years (Ford 1965, Haaker 1975, Smith \& Daiber 1977, Martínez-Muñoz \& Ortega-Salas 1999, 2001, Mac Nair 2001, Amezcua et al. 2005).

Analysis of the length-weight relationship of males, females, and undetermined shows an allometric growth and differences in the relative growth rate between sexes. However, they are similar (positive allometric growth) to those of Arora (1951) and (Martínez-Muñoz \& Ortega-Salas 1999, 2001) in California and other regions. The length-weight relationship may be influenced by sex, maturity, geographical location, and environmental condition (Bagenal \& Tesch 1978).

The sex ratio in the flatfish species is generally 1:1 (Kramer 1991, Minami \&Tanaka 1992, Martínez-Muñoz \& Ortega-Salas 1999, 2001) as found in this paper.

Values of $\mathrm{k}(0.2)$ are low for both sexes of longfin sanddab, which indicates slow growth. It is expected that the natural mortality rate (0.3) of such a slow-growing, longed-lived species would also be relatively low; estimates of $\mathrm{M}$ from 0.19 to 0.22 have been made for the Alaska plaice) (Pleuronectes quadrituberculatus). Natural mortality is likely close to 0.2 , which is the value used in age-structured modelling of the eastern Bering Sea population (Zhang et al. 1998).

Analysis of the catch curve mortality estimates a relatively high instantaneous total mortality in the longfin sanddab population off western Baja California waters (Table 4). Relatively few are older than five years. The age structure observed in this population may, however, reflect the relatively short life-span of this species (10 years), or it could also reflect high mortality levels experienced by longfin sanddab in Baja California.

The values obtained for annual total mortality; natural mortality; and fishing mortality are first estimations for the longfin sanddab 
TABLE 4

Total mortality (Z) in flatfish species of the Paralichthyidae family

Species

1) Southern flounder

Paralichthys lethostigma

2) Summer Flouder

Paralichthys dentatus

3) Fantail sole

Xystreurys liolepis

4) California halibut

Paralichthys californicus

5) Bigmouht sole

Hippoglossina stomata

6) Longfin sanddab

Citharichthys xanthostigma
Location

Georgia's coastal waters

USA

Southern mid-Atlantic bight

Baja California, México

Southern and central California, USA

Baja California, México

Baja California, México

\begin{tabular}{|c|c|}
\hline Z & Source \\
\hline C: 0.73 & Music \& Pafford (1984) \\
\hline C:0.49 & Desfosse (1995) \\
\hline C: 0.62 & $\begin{array}{l}\text { Martínez-Muñoz \& Ortega-Salas } \\
\text { (1999) }\end{array}$ \\
\hline $\begin{array}{l}\text { M: } 0.91 \\
\text { F: } 0.68\end{array}$ & MacNair et al., (2001) \\
\hline C: 0.69 & $\begin{array}{l}\text { Martínez-Muñoz \& Ortega-Salas } \\
\text { (2001) }\end{array}$ \\
\hline $\begin{array}{l}\text { M: } 0.77 \\
F: 0.78 \\
C: 0.82\end{array}$ & Present paper \\
\hline
\end{tabular}

population from the western coast of Baja California. In spite of the consistency among those age classes included, the mortality should be further investigated, especially with respect to the younger age classes and by using direct methods.

Total mortality and fishing values for other species of flatfish (Table 4), and C. xanthostig$m a$ maintained a similar pattern to the obtained for $H$. stomata and X. liolepis in the same study area; this is caused by the fishing effort that is made in shrimp fishing in the western coast of Baja California, representing high biomass of bycacth (Martínez-Muñoz 2001, MartínezMuñoz \& Ortega-Salas 1999, 2001).

The Citharichthys species, like the Pacific sanddab, is harvested commercially by bottom fishermen using other trawls (Frey 1971). The longfin sanddab ranked first in abundance among fish species collected in trawl surveys conducted from 1988-1990 off the Baja California shelf (Ramírez-Cruz \& Martínez-Muñoz 1992).

Off the western coast of Baja California, a high fishing mortality of flatfishes, including longfin sanddab, occurs, resulting from intensive trawl fishing for shrimp (Ehrhardt et al. 1982, van der Heiden et al. 1985). Although longfin sanddab is not a target species of these commercial shrimp fisheries, the rate of fishing mortality is estimated to be greater than the natural mortality, as a result of the large bycatch of flatfishes along the western coast of Baja California (Martínez-Muñoz \& Ortega-Salas 2001), which also includes the Bigmouth sole (H. stomata), Fourspot sole (H. tetrophthalma), Spotted flounder (H. bollmani), California halibut ( $P$. californicus), Fantail sole (X. liolepis), Gulf sanddab (C. fragilis), (Pleuronichthys ritteri), California tonguefish (Symphurus atricauda), among others.

The longfin sanddab attains a size enough to become bycatch at 2 years and is considered a potential exploitable flatfish, but needs to have regulations as a fishery resource.

Hence, the fishing mortality, mainly due to bycatch in the shrimp fishery, is greater than the natural mortality, which means that $C$. xanthostigma is overexploited.

\section{ACKNOWLEDGMENTS}

This study was partially supported by the Consejo Nacional de Ciencia y Tecnología de México (CONACYT), grant P22OCC0R880518, and Universidad Nacional Autónoma de México, which provided the B/O "El Puma" from 1988 to 1991 . We also thank the Instituto de Ciencias del Mar y Limnología 
(UNAM) for permitting us to analyze the information, the "Centro de Investigaciones Biológicas del Noroeste" for processing the raw material, to A. Nuñez P. and C. Ramírez for their technical support.

\section{RESUMEN}

Se presenta información sobre el crecimiento y mortalidad de la población del C. xanthostigma (lenguado alón) en el Pacífico Mexicano de Baja California, México. Datos sobre su crecimiento fueron obtenidos de peces capturados con red de arrastre durante seis cruceros en la costa Oeste de Baja California, México. Se capturaron 1017 peces en este periodo. La relación machos:hembras de 860 ejemplares fue de 1:1.2. La relación peso total (W) y longitud estándar (SL) se estimó para hembras: W=0.00000743 $\mathrm{SL}^{3.196}$ y para machos: $\mathrm{W}=0.00000764 \mathrm{SL}^{3.193}$. La edad de los grupos se calculó con datos de frecuencia por longitud, el crecimiento de von Bertalanffy global fue: $\mathrm{L}_{\infty}=289.2 \mathrm{~mm}$ $\mathrm{SL}, \mathrm{k}=0.20, \mathrm{t}_{0}=-0.73$; para los machos: $\mathrm{L}_{\infty}=265.9 \mathrm{~mm} \mathrm{SL}$, $\mathrm{k}=0.21, \mathrm{t}_{0}=-0.68$ y para las hembras: $\mathrm{L}_{\infty}=293.6 \mathrm{~mm} \mathrm{SL}$, $\mathrm{k}=0.23, \mathrm{t}_{0}=-0.35$, anualmente. La captura de $C$. xanthostigma durante este estudio alcanzó una edad máxima de 10 años. Los machos alcanzan tallas menores que las hembras a la misma edad. Los grupos de edad tuvieron una tasa de mortalidad total $(\mathrm{Z})$ de 0.82 por año, una mortalidad por pesca (F) de 0.52 por año y mortalidad natural (M) de 0.3 por año. Aunque el C. xanthostigma no es una especie objetivo (comercial), sufre una alta mortalidad indirecta durante la pesca del camarón.

Palabras clave: lenguados, pleuronectiformes C. xanthostigma, crecimiento, mortalidad, captura incidental camarón, Baja California.

\section{REFERENCES}

Abitia-Cárdenas, L.A., J. Rodríguez-Romero, F. GalvánMagaña, J. de la Cruz-Agüero \& H. Chávez-Ramos. 1994. Lista sistemática de la ictiofauna de Bahía de la Paz, Baja California Sur, México. Cienc. Mar. 20: 159-181.

Allen, M.J. 1982. Functional structure of soft-bottom fish communities of the Southern California shelf. Ph.D. Thesis, University of California, California, USA.

Allen, M.J. \& R. Leos. 2001. Sanddabs, p. 201-202. In W.S. Leet, C.M. Dewees, R. Klingbiel \& E.J. Larson (eds.). California's Living Marine Resources: A status report. California Department of Fish and Game. University of California Agriculture and Natural Resources, California, USA, Sea Grant Publication SG01-11: 201-202.
Amezcua, F., I. Martínez-Tovar, Y. Green-Ruiz \& F. Amezcua-Linares. 2005. Use of otoliths to determine age and growth of a tropical flatfish Cyclopsetta querna (Paralichthyidae) from the southeast coast of the Gulf of California, México. Ichth. Res. 53: 70-74.

Anderson, R.O. \& R.M. Neumann. 1996. Length, weight, and associated structural indices, p. 447-481. In B.R. Murphy \& D. Wills (eds.). Fisheries techniques. American Fisheries Society, Bethesda, Maryland, USA.

Arora, H.L. 1951. An investigation of the California sanddab Citharichthys sordidus (Girard). Calif. Depart Fish Game Fish Bull. 37: 3-42.

Balart, E.F. 1996. Pesquería de lenguados, p. 273-285. In M. Casas-Valdez \& G. Ponce-Díaz (eds.). Estudio del Potencial Pesquero y Acuícola de Baja California Sur. Vol. I. SEMARNAP. FAO. INP. UABCS. CIBNOR. CICIMAR. UECYTM. La Paz, Baja California Sur, México.

Bagenal, T.B. \& F.W. Tesch. 1978. Methods for assessment of fish production in freshwater. IBP handbook $\mathrm{N}^{\mathrm{o}} 3$. Blackwell, London, England.

Beverton, R.J.H. \& S.J. Holt. 1957. On the dynamics of exploited fish populations. Fishery Investigations Series II, Marine Fisheries, Great Britain Ministry of Agriculture, Fisheries and Food 19. London, England.

Castro-Aguirre, J.L., J.C. Ramírez-Cruz \& M.A. MartínezMuñoz. 1992. Nuevos datos sobre la distribución de los lenguados (Pisces: Pleuronectiformes) en la costa oeste de Baja California, México; aspectos biológicos. An. Esc. Nac. Cienc. Biol. Méx. 37: 97-119.

Chamberlain, D.W. 1979. Histology of there productive systems and comparison of selected morphological characters in four Eastern Pacific species of Citharichthys (Pisces: Bothidae). Ph.D. Thesis, University of Southern California, California, USA.

Chen, Y., D.A. Jackson \& H.H. Harvey. 1992a. A comparison for von Bertalanffy and polynomial functions in modelling fish growth data. Can J Fish Aquat Sci. 49:1228-1235.

Chen, D., L. Changan, \& D. Shuozeng. 1992b. The biology of flatfish (Pleuronectidae) in the coastal waters of China. Neth. J. Sea Res. 29: 25-33.

De la Cruz-Agüero, J., F. Galván-Magaña, L.A. AbitiaCárdenas, J. Rodríguez- Romero \& F.J. GutiérrezSánchez. 1994. Lista sistemática de los peces marinos de Bahía Magdalena, B.C.S., México. Cienc. Mar. 20: 17-31. 
Desfosse, J.C. 1995. Movements and ecology of summer flounder, Paralichthys dentatus, tagged in the southern mid-Atlantic bight. Ph.D. Thesis, College of William and Mary, Virginia, USA.

Ehrhardt, N.M., E.M. Ramírez, P. Aguilera, P. Jacquemin, M. Lozano \& I. Romo. 1982. Evaluación de los recursos demersales accesibles a redes de arrastre de la plataforma continental de la costa occidental de la península de Baja California, México, durante 1979 y 1980. Prog. Inv. Des. Pesq. Integr. México. PNUD/ FAO/INP. Serie Científica 23: 46 pp.

Eschmeyer, W.N., E.S. Herald \& H. Hammann. 1983. A field guide to Pacific Coast Fishes of North America from the Gulf of Alaska to Baja California. The Peterson Field Guide Series. Houghton Mifflin, Boston, USA. 28: 336.

Ford, R.F. 1965. Distribution, population dynamics, and behavior of a bothid flatfish, Citharichthys stigmaeus. Ph.D. Thesis, University of Calififornia, San Diego, California, USA.

Frey, H.W. 1971. California's living marine resources, and their utilization. Calif. Dep. Fish and Game, California, USA.

Froese, R. \& C. Binohlan. 2000. Empirical relationships to estimate asymptotic length, length at first maturity, and length at maximum yield per recruit in fishes, with a simple method to evaluate length frequency data. J Fish Biol. 56: 758-773.

Gayanilo, F.C., P. Sparre \& D. Pauly. 1994. The FAOICLARM Stock Assessment Tools (FISAT) User's Guide. FAO Computerized Series. Fisheries No. 6. Rome, Italy.

Goldberg, S.R. 1982. Seasonal spawning cycle of the longfin sanddab, Citharichthys xanthostigma (Bothidae). Fish. Bull. U.S. 80: 906-907.

Gulland, J.A. 1983. Fish stock assessment. Manual of basic methods. Wiley, New York, USA.

Haaker, P.L. 1975. The biology of the California halibut Paralichthys californicus (Ayres) in Anaheim Bay, p. 137-151. In E.D. Lane \& C.W. Hill (eds.). The marine resources of Anaheim Bay. Calif. Depart. Fish Game. Fish Bull. 165

Kramer, S.H. 1991. The shallow-water flatfish of San Diego County. Rep. Calif. Coop. Fishery Invest. 32: 128-141.

King, M. 1995. Fisheries Biology, Assessment and Management. Fishing News Books, Oxford, England.
MacNair, L.S., M.L. Domeier \& C.S.Y. Chun. 2001 Age, growth, and mortality of California halibut, Paralichthys californicus, along southern and central California. Fish Bull. 99: 588-600.

Martínez-Muñoz, M.A. 2001. Variación espacio-temporal de la abundancia, estructura poblacional y aspectos reproductivos del lenguado de dos manchas Xystreurys liolepis (Jordan \& Gilbert 1881), en la Costa Oeste de Baja California Sur, México. 2001. Tesis Maestría, Centro Interdisciplinario de Ciencias Marinas, Instituto Politécnico Nacional, La Paz, Baja California Sur, México.

Martínez-Muñoz, M.A. \& A.A. Ortega-Salas. 1999. Growth and Mortality of the Fantail Sole, Xystreurys liolepis (Jordan \& Gilbert 1881) off the Western Coast of Baja California, México. Bull. South Calif. Acad. Sci. 98: 66-74.

Martínez-Muñoz, M.A. \& A.A. Ortega-Salas. 2001. Growth and Mortality of the Bigmouth Sole, Hippoglossina stomata Eigenmann \& Eigenmann, 1890 (Pisces: Paralichthyidae) off the Western Coast of Baja California, México. Bull Mar. Sci. 69: 1109-1119.

Miller, D.J. \& R.N. Lea. 1972. Guide to the coastal marine fishes of California. Calif. Depart. Fish Game, Fish Bull. 157.

Minami, T. \& M. Tanaka. 1992. Life history cycles in flatfishes from the Northwest Pacific, with particular reference to their early life histories. Neth. J. Sea Res. 29: $35-48$.

Moser, H.G. \& B.Y. Sumida. 1996. Paralichthyidae: Lefteye flounders and sanddabs, p. 1325-1355. In H.G. Moser (ed.). The early stages of fishes in the California Current Region. Rep. Calif. Coop. Fishery Invest. Atlas No. 33.

Moyle, P.B. \& J.J. Cech Jr. 1988. Fishes: An Introduction to Ichthyology. Prentice-Hall, New Jersey, USA.

Music, J.L. \& J.M. Pafford. 1984. Population dynamics and life history aspects of major marine sportfishes in Georgia's coastal waters. Georgia Dep. Nat. Res., Coast Res. Div., Contr. Ser. 38: 1-382.

Pérez-Mellado, J. \& L.T. Findley. 1985. Evaluación de la íctiofauna acompañante del camarón capturado en las costas de Sonora y Norte de Sinaloa, México, p. 201-253. In A. Yañez-Arancibia (ed.). Recursos pesqueros potenciales de México: la pesca acompañante del camarón. Universidad Nacional Autónoma de México-Instituto Nacional de la Pesca, México, D.F., México. 
Pauly, D. 1980. On the interrelationships between natural mortality, growth parameters, and mean environmental temperature in 175 fish stocks. J. Cons. Int. Explor. Mer. 39: 175-192.

Pauly, D. 1983. Some simple methods for assessment of tropical fish stocks. FAO Fisheries Techn. Pap. $N^{\circ}$ 234.

Pauly, D. \& N. David. 1981. ELEFAN I, a basic program for the objective extraction of growth parameters from length-frequencies data. Meeresforschung 28: 205-211.

Ramírez-Cruz, J.C. \& M.A. Martínez-Muñoz. 1992. Distribución y abundancia de Pleuronectiformes (Teleostei) en la costa occidental de Baja California Sur, México. Tesis Profesional, Universidad Nacional Autónoma de México, Baja California Sur, México.

Ricker, W.E. 1975. Computation, and interpretation of biological statistics of fish populations. Bull. Fish. Res. Board Can. 191.

Rodríguez-Romero, J., L.A. Abitia-Cárdenas, F. GalvánMagaña \& H. Chávez-Ramos. 1994. Composition, abundance and specific richness of fishes from Concepcion Bay, Baja California Sur, México. Cienc. Mar. 20: 321-350.

Rodríguez-Romero, F., D.S. Palacios-Salgado, J. LópezMartínez, S. Hernández-Vázquez \& G. Ponce-Díaz. 2008. Composición taxonómica y relaciones zoogeográficas de los peces demersales de la costa occidental de Baja California Sur, México. Rev. Biol. Trop. 56: $1765-1783$.
Rosales-Casián, J.A. 1996. Ictiofauna de la Bahía de San Quíntin, Baja California, México, y su costa adyacente. Cienc. Mar. 22: 443-458.

Smith, R.W. \& F.C. Daiber. 1977. Biology of the summer flounder, Paralichthys dentatus in Delaware Bay. Fish. Bull. 75: 823-830.

Sokal, R.R. \& F.J. Rohlf. 1995. Biometry: The principles and practice of statistics in biological research. Freeman, New York, USA.

Sparre, P. \& S.C. Venema. 1992. Introduction to tropical fish stock assessment. FAO Fish. Tech. Pap. 306/1. Rev. 1.

van der Heiden, A.M. 1985. Taxonomía, biología y evaluación de la ictiofauna demersal del Golfo de California, p.149-200. In A. Yañez-Arancibia (ed.). Recursos pesqueros potenciales de México: la pesca acompañante del camarón. Universidad Nacional Autónoma de México-Instituto Nacional de la Pesca, México D.F., México.

Weatherly, A.H. \& H.S. Gill. 1987. The Biology of Fish Growth. Academic, New York, USA.

Wooton, R.J. 1990. Ecology of Teleost Fish. Chapman and Hall, London, England.

Zar, J.H. 1999. Biostatistical analysis. Prentice Hall, New York, USA.

Zhang, C.I., T.K. Wilderbuer \& G.E. Walters. 1998. Biological characteristics and fishery assessment of Alaska Plaice, P. quadrituberculatus, in the eastern Bering Sea. U.S. Natl. Mar. Fish. Serv. Mar. Fish. Rev. 60: 16-27. 
